\title{
The Reliability of Quantifying the Pancreatic Ductus in Predicting the Operability of Pancreatic Adenocarcinomas
}

\section{Pankreas Adenokarsinomlarında Operabilitenin Belirlenmesinde Pankreatik Kanal Çapının Güvenilirliği}

\author{
Abdussamet Batur', (1) Fatma Durmaz ${ }^{2}$ \\ 'Selcuk University School of Medicine, Department of Radiology, Konya, Turkey \\ ${ }^{2}$ Hakkari State Hospital, Hakkari, Turkey
}

\begin{abstract}
Aim: To evaluate the quantifying of the pancreatic ductus in predicting the operability of pancreatic adenocarcinomas Material and Method:We reviewed the clinical and imaging data of 30 patients (21 men, 9 women; mean age, 64.2 years; age range 41-93 years) who had histopathologically proven pancreatic head adenocarcinoma, and underwent multidetector CT for their initial nonspesific symptoms before the diagnosis was rendered. Accompanying secondary signs also were analysed.

Results: Thirty patients with pancreatic head adenocarcinoma were evaluated. Thirteen of them (43.3\%) were found to be operable (Group $A$ ) and seventeen of them (56.7\%) were found to be inoperable (Group B) radiologically and surgically. The mean caliber of the dilated pancreatic duct in Group A patients was $5.80 \mathrm{~mm}$, and in Group B pateints was $9.15 \mathrm{~mm}(p=0.001)$. The ratio of pancreatic duct caliber to gland width was 0.46 in Group A and was 0.62 in Group B $(p=0.001)$. Accompanying secondary signs such as choledoch dilatation, tumor size, and initial complaints showed no significant difference between the two groups.

Conclusion: The main pancreatic duct diameter and/or a ratio of duct to gland width can be useful in predicting the operability of pancreatic adenocarcinomas
\end{abstract}

Keywords: Computed tomography, pancreatic adenocarcinoma, pancreatic duct, operability
Öz

Amaç: Pankreas adenokarsinomlarının operabilitesini öngörmede pankreas kanalının çapını değerlendirmek.

Gereç ve Yöntem: Histopatolojik olarak kanıtlanmış pankreas baş adenokarsinomu olan ve tanıdan önce nonspesifik semptomları nedeniyle multidetektör bilgisayarlı tomografi uygulanan 30 hastanın (21 erkek, 9 kadın; ort. yaş, 64.2 yıl; yaş aralığı 41-93 yıl) klinik ve görüntüleme bulgularını inceledik. Eşlik eden sekonder bulgular da analiz edildi.

Bulgular: Pankreas başı adenokarsinomu olan 30 hasta değerlendirildi. Bunlardan 13'ünün (\% 43,3) operabl olduğu (A Grubu) ve 17 'sinin $(\% 56,7)$ radyolojik ve cerrahi olarak inoperabl olduğu (B Grubu) bulundu. Grup A hastalarında dilate pankreas kanalının ortalama çap 5.80 mm ve Grup B hastalarında 9.15 mm ölçüldü ( $p=0.001)$. Pankreas kanalı çapının bez genişliğine oranı Grup A'da 0.46 ve Grup B'de 0.62 bulundu ( $p=0.001$ ). Koledok dilatasyonu, tümör büyüklüğü ve ilk başvuru şikayetleri gibi eşlik eden sekonder belirtiler iki grup arasında anlamlı bir farklılık göstermedi.

Sonuç: Ana pankreas kanalı çapı ve/veya kanal çapının bez genişliğine oranı, pankreas adenokarsinomlarının operabilitesini öngörmede faydalı olabilir.

Anahtar Kelimeler: Biligisayarlı tomografi, pankreatik adenokarsinom, pankreatik kanal, operabilite 


\section{INTRODUCTION}

Pancreatic adenocarcinoma is the 9th most common malignancy; however, it is the 4th among the malignancies with the highest mortality. ${ }^{[1-3]}$ Its prognosis is very poor, but the 5-year survival increases in patients with the chance of curative surgery. ${ }^{[4]}$ However, the curative surgery at diagnosis is possible only in $10-20 \%$ of the patients and generally concomitant metastasis or co-existence of invasion to the adjacent structures is observed at diagnosis. ${ }^{[2,4,5]}$

The presence of metastasis is detected at diagnosis in almost $45 \%$ of the patients with pancreatic adenocarcinoma and the presence of peripancreatic vascular invasion, the criterion for inoperability, is also observed in $40 \%$. However, the development of newer vascular reconstruction techniques and the improvements in neoadjuvant therapies have now made disease with limited vascular involvement potentially resectable. ${ }^{[6]}$ The survival is limited to a few month in inoperable cases, whereas the 5-year survival is around $20 \%$ in patients with chance of surgery; this rate increases up to $75 \%$ in cases of stage $1 .{ }^{[5,7]}$ Therefore, early detection of the lesions is of great importance for the chance of curative surgery, and thereby achieving an extended survival. Although the pancreatic masses of early stage are mostly in small size, all of the small-size pancreatic mass lesions do not represent the early stage. ${ }^{[8]}$ This is thought to be resulted from the early extension of pancreatic adenocarcinomas over the adjacent tissues through perineural ways. ${ }^{[9]}$

Pancreatic adenocarcinoma cases are evaluated by using various imaging techniques, and the multidetector Computed Tomography (CT) is considered as the most elective imaging method. ${ }^{[6]}$ The main purpose of CT imaging is to demonstrate the mass and to evaluate the resectability. The positive predictive value of $C T$ at the evaluation of non-resectable pancreatic masses is $89-100 \%$, while its specificity for assessment is lower in predicting resectable lesions. ${ }^{[10-12]} \mathrm{A}$ substantial part of the patients considered resectable from the evaluation by CT assessment are found to be inoperable during the operations. ${ }^{[13]}$

The present study aimed to evaluate the association of the pancreatic duct diameter and duct diameter/parenchymal thickness ratio with the resectability of masses in cases with adenocarcinoma in the head of the pancreas; and thereby to establish the reliability of these parameters in evaluating the resectability of masses in the head of the pancreas.

\section{MATERIAL AND METHOD}

\section{Patients}

The abdominal CT assessments of 93 patients with pancreatic adenocarcinoma (mean age: 58.4 $\pm 9.6 ; 57$ male, 36 female), who were histopathologically diagnosed after sampling by postoperative or minimal invasive surgical methods between June 2009-December 2013 were retrospectively examined. The pancreatic masses other than localized in the head of the pancreas and the non-adenocarcinoma lesions were excluded from the study; additionally, the patients with a detected lesion in the head of the pancreas but who had choledochal stent or surgical intervention were also excluded. In conclusion, 30 patients who were not previously diagnosed and diagnosed with mass in the head of the pancreas at admission to our institution with symptomatic complaints for the first time (21 male, 9 female; mean age: 64.2 years; age range: $41-93$ years) were included in the study; the $\mathrm{CT}$ assessments of the patients were retrospectively examined. Additionally, the complaints of the patients at admission were classified as obstructive $(n=15)$ (jaundice and/or pruritus), non-obstructive $(n=12)$ (abdominal pain, weight loss, incidental (1)) and coexistence of both $(n=3)$.

\section{CT Technique}

$\mathrm{CT}$ assessments were performed with Siemens Somatom AR Star (Erlanger, Germany). Standard scanning parameters were $130 \mathrm{kVp}$ and $83 \mathrm{~mA}$, and the slice thickness was $3 \mathrm{~mm}$, and the pitch ratio was 1 . After a 6 to 8 -hour fasting achieved in all patients, $2 \mathrm{ml} / \mathrm{kg}$ iodized contrast agent was intravenously administered at $4 \mathrm{ml} / \mathrm{s}$ via an automatic injector to obtain contrast-enhanced sections. Non-ionic agents containing $150 \mathrm{mg} / \mathrm{ml}$ iodine were used as the contrast agent. Images were obtained at the 70th second following contrast agent injection.

\section{Image Analysis}

All images were evaluated through a workstation (Siemens Leonardo, Erlangen, Germany). CT sections were analyzed and the ratio of pancreatic duct diameter, pancreatic parenchymal thickness and pancreatic duct width to parenchyma was measured. Additionally, the mass sizes were recorded and the operability of the masses was evaluated radiologically. The invasion findings and if any, the metastatic lesions of the patients considered as inoperable were recorded. The pancreatic duct width $>3 \mathrm{~mm}$ was considered as dilated. The choledochus $>7 \mathrm{~mm}$ in patients below 60 years of age, $>9 \mathrm{~mm}$ in patients above 60 years of age and $>10 \mathrm{~mm}$ in patients who had cholecystectomy was considered dilated. ${ }^{[5,14]}$ The gallbladder pathology was evaluated for hydrops. The gallbladder transverse diameter $>40 \mathrm{~mm}$ was considered as hydropic (Figure 1). ${ }^{[15]}$ The intrahepatic bile ducts were evaluated as either normal or dilated. Distal atrophy was defined as parenchyma in the distal of the mass. The pancreatic duct diameter and duct/parenchyma ratio (including duct diameter) were measured at the widest part of dilatation (Figure 2). ${ }^{[16]}$ The presence of distant organ metastasis or adjacent tissue invasion was taken as the main criteria for the evaluation of inoperability. The arterial invasion was considered as the vascular circumferential contact of $>180$ degrees, between the mass and the vessel and the venous invasion was considered as the vascular circumferential contact of $>270$ degrees between the mass and the vessel or the demonstration of intraluminal invasion (Figure 3). ${ }^{[17,18]}$ 


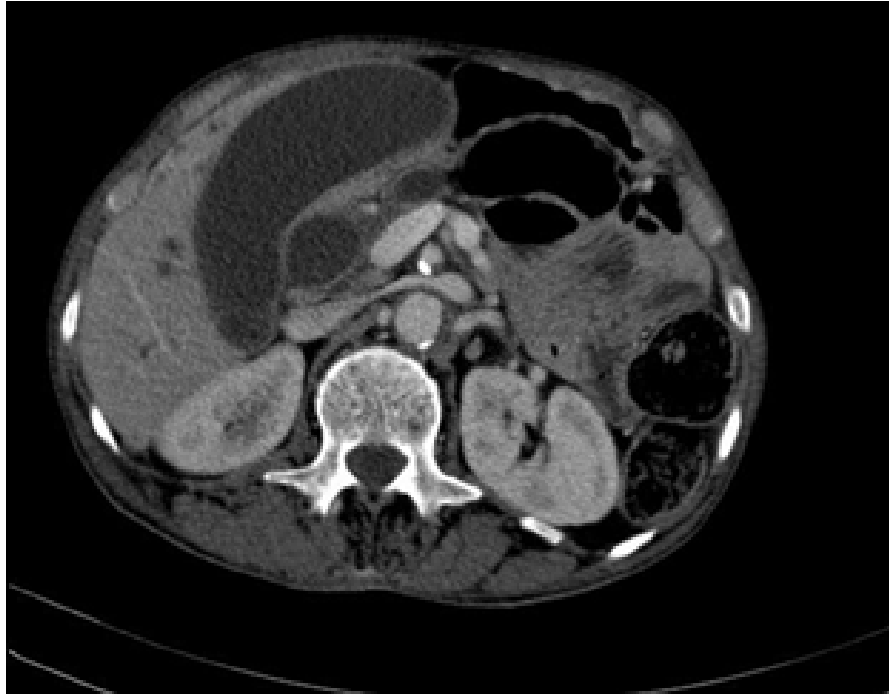

Figure 1. Axial contrast-enhanced computed tomography demonstrating hydroipc gallbladder with transverse diameter more than $40 \mathrm{~mm}$.

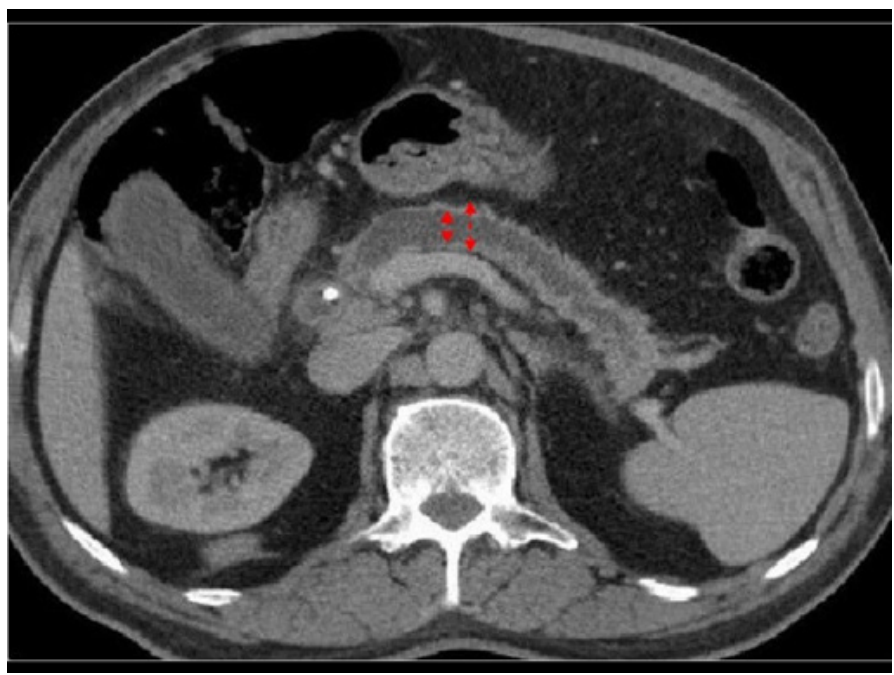

Figure 2. Axial contrast-enhanced computed tomography demonstrating the ratio of pancreatic duct caliber to width of gland (including duct).

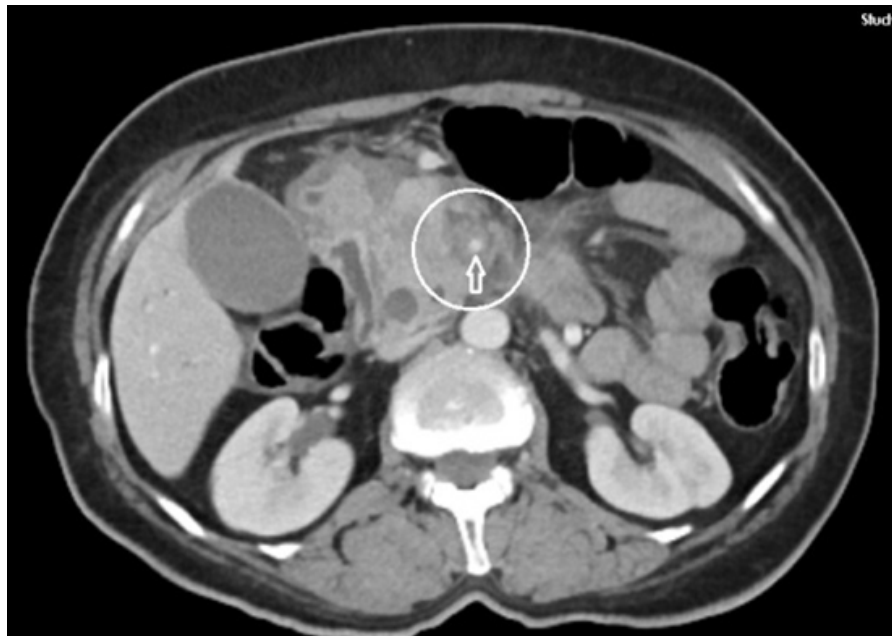

Figure 3. Axial contrast-enhanced computed tomography demonstrating superior mesenteric artery invasion (arrow) with vascular circumferentia contact of $>180$ degrees (in circle), between the mass and the vessel.

\section{Statistical Analysis}

Descriptive statistics for studied variables (characteristics) were presented as median, mean, standard deviation, minimum and maximum values. Student $t$ test was used to compare group means for the studied variables. For determination linear relations among the variables, Pearson correlation analysis was carried out. Cut off value of pancreatic duct and duct/gland width were determined by ROC analysis. Statistical significance levels were considered as $5 \%$. The SPSS (ver. 13) statistical program was used for all statistical computations.

\section{RESULTS}

The CT images of 30 patients who were diagnosed with adenocarcinoma in the head of the pancreas at initial admission were retrospectively evaluated. It was found that only 1 of 14 patients who were considered operable radiologically (Group A) was inoperable due to portal venous invasion during the operation. Of $17(56.7 \%)$ patients considered inoperable (Group B); 6 (35.3\%) had vascular invasion, 3 (17.6\%) had vascular invasion and metastasis, 4 (23.5\%) had metastasis, 3 (17.6\%) had adjacent organ invasion and 1 (5.9\%) had vascular and adjacent organ invasion (Figure 4A, B, C).
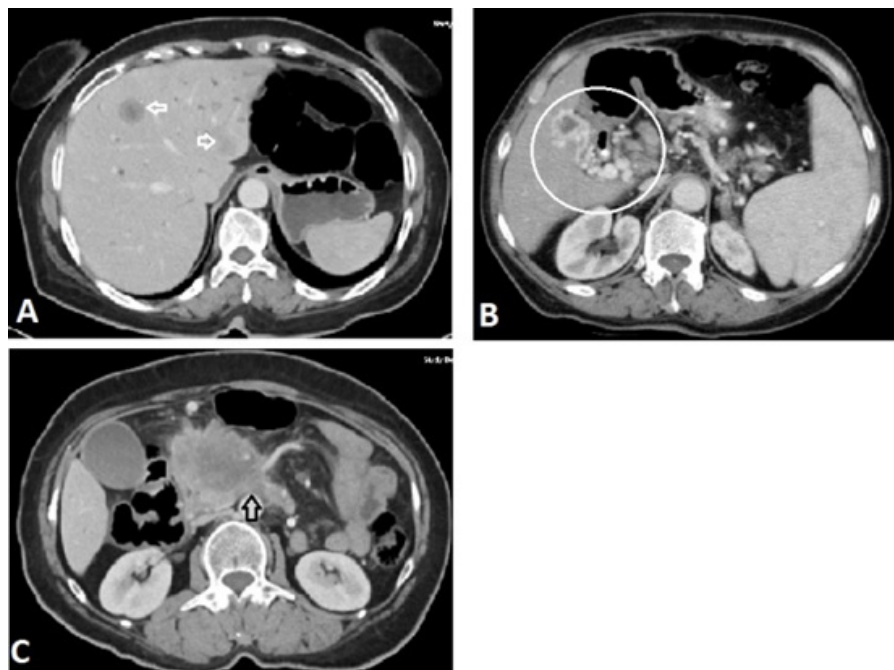

Figure 4. Axial contrast-enhanced computed tomography demonstrating patients considered inoperable with (A) hepatic metastasis, (B) vascular invasion resulting in cavernous transformation (in circle), and (C) duodenal invasion.

In Group A patients; the mean age was $65.54 \pm 10.43$ years, the mean pancreatic duct diameter was $5.80 \pm 1.60 \mathrm{~mm}$, the mean choledochus diameter $15.38 \pm 3.98 \mathrm{~mm}$, the pancreatic duct/parenchymal thickness (including duct) ratio was 0.462 and the mean mass widest axial size was $3.06 \pm 0.76 \mathrm{~cm}$. In Group B patients; the mean age was $63.18 \pm 13.79$ years, the mean pancreatic duct diameter was $9.15 \pm 2.94 \mathrm{~mm}$, the mean choledochus diameter $16.87 \pm 3.34 \mathrm{~mm}$, the duct/parenchymal thickness (including duct) ratio was 0.627 and the mean mass widest axial size was $4.17 \pm 1.61 \mathrm{~cm}$. For all patients; the mean age was $64.2 \pm 12.3$ years, the mean pancreatic duct diameter was $7.7 \pm 2.94 \mathrm{~mm}$, the mean choledochus diameter $16.23 \pm 3.64 \mathrm{~mm}$, the duct/parenchymal thickness (including duct) ratio was 0.55 and the mean mass widest axial size was $3.69 \pm 1.40 \mathrm{~cm}$ (Table 1). 
Table 1. Descriptive statististics

\begin{tabular}{|lccccc|}
\hline & N & Minimum & Maximum & Mean & SD \\
\hline Pancreatic duct $(\mathrm{mm})$ & 30 & 3 & 15 & 7.70 & 2.944 \\
Choledoch $(\mathrm{mm})$ & 30 & 8 & 23 & 16.23 & 3.644 \\
Duct/Gland Width & 30 & .3 & .8 & .555 & .1422 \\
Age (year) & 30 & 41 & 93 & 64.20 & 12.305 \\
Tumor Size (cm) & 30 & 2 & 8 & 3.69 & 1.405 \\
\hline SD: Standart Deviation & & & & & \\
\hline
\end{tabular}

Patients were evaluated in 3 categories based on their complaints at initial admission; obstructive, non-obstructive and co-existence of both. Of the patients $(n=30) ; 15(50 \%)$ presented with obstructive complaints (operable $=7$, inoperable $=8), 12(40 \%)$ with non-obstructive complaints (operable $=6$, inoperable $=6$ ) and $3(10 \%)$ with both obstructive and non-obstructive complaints (all inoperable). The statistical assessment did not reveal any statistically significant difference in operability between the patients presenting with obstructive and non-obstructive complaints based on the complaints at initial admission $(p=0.275)$. The presentation and descriptive statistics and the comparison results of the patients at initial admission are presented in Tables $\mathbf{2}$ and $\mathbf{3}$. When the pancreatic duct diameter was used to differentiate the operable and inoperable adenocarcinoma (Group A and
Group B) among the patients included in the study, the power of differentiation was found to be $85.3 \%(p=0.001)$; and when the duct diameter/parenchymal thickness ratio was used, this value was found to be $86 \%(p=0.001)$ (Figure 5). When the cut-off value for the duct diameter was taken as $6.8 \mathrm{~mm}$, the sensitivity and specificity were calculated as $82.4 \%$ and $84.6 \%$, respectively. When the cut-off value for the duct diameter/ parenchyma ratio was taken as 0.5 , the sensitivity and specificity were calculated as $94.1 \%$ and $76.9 \%$, respectively.

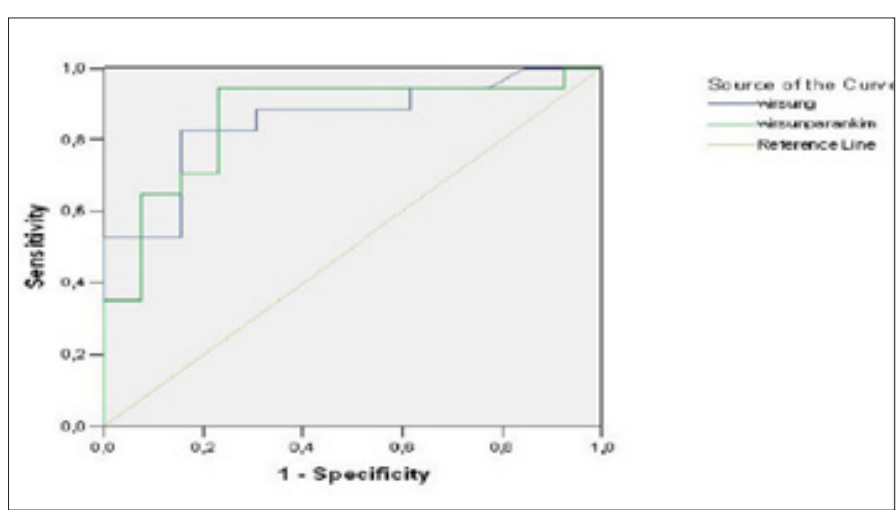

Figure 5. ROC curve. The relationship of duct caliber and pancreatic duct width to parenchyma between operability were evaluated. Area under the curve is 0.853 and 0.860 for duct caliber and the ratio, respectively.

\begin{tabular}{|c|c|c|c|c|c|c|c|}
\hline & presentation & Mean & Median & St. Dev. & Maximum & Minimum & $\mathbf{p}$ \\
\hline \multirow[b]{2}{*}{ Pancreatic duct (mm) } & 0 & 8.23 & 8.60 & 2.92 & 12.80 & 3.20 & .489 \\
\hline & 1 & 7.37 & 6.55 & 3.30 & 15.00 & 3.70 & \\
\hline \multirow[b]{2}{*}{ Choledoch (mm) } & 0 & 16.46 & 17.10 & 3.91 & 21.00 & 8.20 & .598 \\
\hline & 1 & 16.16 & 15.55 & 3.79 & 23.00 & 12.00 & \\
\hline \multirow[t]{2}{*}{ Duct/Gland Width } & 1 & .53 & .52 & .11 & .72 & .35 & \\
\hline & 2 & .50 & .52 & .17 & .66 & .33 & \\
\hline \multirow{3}{*}{ Age (year) } & 0 & 65.87 & 59.00 & 14.29 & 93.00 & 49.00 & .307 \\
\hline & 1 & 65.00 & 62.00 & 8.92 & 83.00 & 53.00 & \\
\hline & 2 & 52.67 & 57.00 & 10.21 & 60.00 & 41.00 & \\
\hline
\end{tabular}

\begin{tabular}{|c|c|c|c|c|c|c|c|}
\hline & Operability & Mean & Median & St. Dev. & Maximum & Minimum & $\mathbf{p}$ \\
\hline \multirow{2}{*}{ Pancreatic duct (mm) } & 0 & 5.80 & 5.80 & 1.60 & 8.60 & 3.20 & \multirow[t]{2}{*}{.001} \\
\hline & 1 & 9.15 & 8.90 & 2.94 & 15.00 & 4.50 & \\
\hline Choledoch (mm) & 1 & 16.87 & 17.00 & 3.34 & 23.00 & 12.00 & .276 \\
\hline Duct/Gland Width & 0 & .46 & .48 & .11 & .69 & .30 & .001 \\
\hline Age (year) & 1 & 63.18 & 59.00 & 13.79 & 93.00 & 41.00 & .345 \\
\hline \multirow{2}{*}{ Tumor Size (cm) } & 0 & 3.06 & 3.20 & .76 & 4.00 & 1.50 & \multirow[t]{2}{*}{.028} \\
\hline & 1 & 4.17 & 4.10 & 1.61 & 8.00 & 1.80 & \\
\hline
\end{tabular}




\section{DISCUSSION}

The association between pancreatic duct dilatation and pancreatic cancer was first reported by Burger and Blaunstein in 1974. In the later years, studies were reported about the role of the duct abnormalities in the differentiation of pancreatic cancer and pancreatitis. ${ }^{[19]}$ The pancreatic ductto-parenchyma ratio also can be helpful in determining the degree of suspicion for malignancy. At endoscopic US, a pancreatic duct to parenchyma ratio of greater than 0.34 strongly favors the diagnosis of malignancy. In patients with a pancreatic duct-to-parenchyma ratio of greater than 0.34 , there is marked upstream pancreatic ductal dilatation with marked parenchymal atrophy, which are the imaging hallmarks of cancer. Relatively mild ductal dilatation with mild upstream parenchymal atrophy. ${ }^{[19]}$ Other than malignancy or non-neoplastic inflammation, benign lesions such as intraductal papillary mucinous neoplasm (IPMN) can also lead to dilatation. Main pancreatic duct dilatation could represent an indirect sign of the presence of neoplastic papillae growing into the duct, too. ${ }^{[20]}$ Although, there have been recent studies on the significance of duct abnormalities in the mass detection, we could not identify any studies aimed at investigating the association of duct dilatation and operability in the current literature based on our research. ${ }^{[19]}$ The present study investigated the association of pancreatic duct diameter and duct/parenchymal thickness ratio with resectability in the adenocarcinomas in the head of the pancreas and the potential to use these parameters in predicting operability or inoperability.

Adenocarcinomas account for $90-95 \%$ of the primary pancreatic malignancies and $60-65 \%$ of these are localized in the head of the pancreas. ${ }^{[21,22]}$ Symptoms are variable and non-specific; but the most common are weight loss, pain and jaundice. The present study investigated the association of symptoms with resectability by categorizing symptoms as obstructive and non-obstructive, and no statistical significance was found $(p=0.275)$. The present study found no statistical significance between presentation and pancreatic duct diameter $(p=0.489)$; choledochus diameter $(p=0.598)$; duct/parenchyma ratio $(p=0.512)$; age $(p=0.307)$ and mass size $(p=0.645)$.

The inoperability criteria for pancreatic adenocarcinoma include metastasis, vascular invasion and adjacent organ invasion. The criteria defined above can be easily evaluated using sectional imaging methods and the positive predictive value of $C T$ for detecting inoperable masses reaches up to $100 \%$ when these criteria are taken as references. ${ }^{[23]}$ However, the negative predictive value of $\mathrm{CT}$, which cannot provide the same level of success for demonstrating the resectable masses, is $80-94 \% .{ }^{[6,24]}$ The primary reason for this fault due to the $\mathrm{CT}$ assessment in evaluating resectability has been reported as the presence of minimal vascular invasions that cannot be demonstrated clearly. ${ }^{[24,25]}$ In the present study, vascular invasion was detected in $1(5.9 \%)$ of 17 patients during the surgery.
Choledochus $^{[19]}$ and main pancreatic duct dilatation (double duct sign) is suggestive of a mass in the head of the pancreas; however, it is reported that this symptom can be seen in benign pathologies, too. ${ }^{[26]}$ In the present study, the choledochus was observed as dilated in all of the cases, and the mean diameter was $15.38 \pm 3.98 \mathrm{~mm}$ in Group A patients and $16.87 \pm 3.34 \mathrm{~mm}$ in Group B patients. There was no statistically significant difference in choledochus diameter between two groups $(p=0.276)$.

The study by Karasawa et al. ${ }^{[16]}$ for the differentiation of pancreatic adenocarcinoma from chronic pancreatitis reported that almost $90 \%$ of the patients with a duct/parenchyma ratio $>0.5$ had carcinoma. However, no information was provided about resectability. In the present study, the duct/ parenchyma ratio was found to be $0.46 \pm 0.11 \mathrm{~mm}$ in Group A compared to $0.63 \pm 0.12$ in Group B. A statistically significant difference was found between two values $(p=0.001)$. The duct/ parenchyma ratio of all patients included in the study $(n=30)$ was calculated as $0.555 \pm 0.142$, and this value is similar to the findings of Karasawa et al. ${ }^{[16]}$ Nevertheless, Karasawa et al. ${ }^{[16]}$ interpreted the ratio of $<0.5$ in favor of benignity, whereas the mean duct/parenchyma ratio was found to be 0.46 in Group A patients in the present study. Given that the pancreatic adenocarcinomas are generally inoperable at initial diagnosis, this difference is understandable. ${ }^{[5]}$ When the cut-off value of duct/parenchymal thickness ratio was taken as 0.5 , it is possible to detect the operable patients with a sensitivity of $94.1 \%$ and a specificity of $76.9 \%$.

In the present study, the pancreatic duct diameter is significantly different in Group A and Group B patients $(p=0.001)$. The mean pancreatic duct diameter was $5.80 \pm$ $1.60 \mathrm{~mm}$ in Group B compared to $9.15 \pm 2.94 \mathrm{~mm}$ in Group B. When the cut-off value of duct diameter was taken as 6.80 , it is possible to detect the operable patients with a sensitivity of $82.4 \%$ and a specificity of $84.6 \%$. When the pancreatic duct diameter was taken as a reference, the power of differentiation was found to be $85.3 \%$ and when the duct/parenchymal thickness ratio was used, this value was found to be $86 \%$. Since the power of differentiation of both techniques is similar, we believe that it will be more practical to use the duct diameter for evaluating operability.

Due to the low socioeconomic and sociocultural level, patients generally come to our center when the symptoms become unbearable and are diagnosed in the inoperable period. And also the operable patients go to larger centers and thereby we cannot obtain the surgical outcome. Therefore, the number of operable and total patients is low in the present study, and this is the most important limitation of the study. The present study is also limited to the inclusion of patients only with the masses localized in the head of the pancreas. Studying duct diameter and duct/parenchyma ratio in adenocarcinomas localized in the head and other parts of the pancreas at more advanced centers may provide significant contribution to the literature. 


\section{CONCLUSION}

Pancreatic adenocarcinomas are aggressive lesions and the survival may significantly improve in patients with a chance of surgery. The pancreatic duct diameter and/or duct/ parenchyma ratio may indicate resectability at high rates in ductal adenocarcinomas. However, large-sample studies are required.

\section{ETHICAL DECLARATIONS}

Ethics Committee Approval: In this research, the data before 2020 was used and the research was concluded before 2020. According to the Regulation on Clinical Researches published in the Official Gazette of the Republic of Turkey with the number 28617 dated 3 November 2015, the ethics committee approval was not obtained in accordance with the article "Retrospective studies are outside the scope of the regulation (article 2- (2))". This study was prepared in accordance with the Law on Protection of Personal Data, by anonymizing patient data and in accordance with the 2013 Brazil revision of the Helsinki Declaration and guidelines for Good Clinical Practice.

Informed Consent: Because the study was designed retrospectively, no written informed consent form was obtained from patients.

Referee Evaluation Process: Externally peer-reviewed.

Conflict of Interest Statement: The authors have no conflicts of interest to declare.

Financial Disclosure: The authors declared that this study has received no financial support.

Author Contributions: All of the authors declare that they have all participated in the design, execution, and analysis of the paper, and that they have approved the final version.

\section{REFERENCES}

1. Smith SL, Rajan PS. Imaging of pancreatic adenocarcinoma with emphasis on multidetector CT. Clin Radiol. 2004;59(1):26-38.

2. Schima W, Ba-Ssalamah A, Kölblinger C, Kulinna-Cosentini C, Puespoek A, Götzinger P. Pancreatic adenocarcinoma. Eur Radiol. 2007;17(3):638-69.

3. Siegel RL, Miller KD, Jemal A. Cancer statistics, 2015. CA Cancer J Clin. 2015;65(1):5-29.

4. Li D, Xie K, Wolff R, Abbruzzese JL. Pancreatic cancer. Lancet. 2004;363(9414):1049-57.

5. Yoon SH, Lee JM, Cho JY, et al. Small $(\leq 20 \mathrm{~mm})$ pancreatic adenocarcinomas: analysis of enhancement patterns and secondary signs with multiphasic multidetector CT. Radiology. 2011;259(2):442-52.

6. Zaky AM, Wolfgang CL, Weiss MJ, Javed AA, Fishman EK, Zaheer A. Tumor-Vessel Relationships in Pancreatic Ductal Adenocarcinoma at Multidetector CT: Different Classification Systems and Their Influence on Treatment Planning. Radiographics. 2017;37(1):93-112.

7. Tsuchiya R, Noda T, Harada N, et al. Collective review of small carcinomas of the pancreas. Ann Surg. 1986;203(1):77-81.

8. Chiang KC, Yeh CN, Lee WC, Jan YY, Hwang TL. Prognostic analysis of patients with pancreatic head adenocarcinoma less than $2 \mathrm{~cm}$ undergoing resection. World J Gastroenterol. 2009;15(34):4305-10.

9. Deshmukh SD, Willmann JrK, Jeffrey RB. Pathways of extrapancreatic perineural invasion by pancreatic adenocarcinoma: evaluation with 3D volume-rendered MDCT imaging. Am J Roentgenol. 2010;194(3):668-74.
10. Bluemke DA, Cameron $\mathrm{J}$, Hruban $\mathrm{RH}$, et al. Potentially resectable pancreatic adenocarcinoma: spiral CT assessment with surgical and pathologic correlation. Radiology. 1995;197(2):381-5.

11. Lu DS, Reber HA, Krasny RM, Kadell BM, Sayre J. Local staging of pancreatic cancer: criteria for unresectability of major vessels as revealed by pancreatic-phase, thin-section helical CT. AJR Am J Roentgenol. 1997;168(6):1439-43.

12. Megibow AJ, Zhou XH, Rotterdam $\mathrm{H}$, et al. Pancreatic adenocarcinoma: CT versus MR imaging in the evaluation of resectability--report of the Radiology Diagnostic Oncology Group. Radiology. 1995;195(2):327-32.

13. Luetmer PH, Stephens DH, Ward EM. Chronic pancreatitis: reassessment with current CT. Radiology. 1989;171(2):353-7.

14. Ahn SS, Kim MJ, Choi JY, Hong HS, Chung YE, Lim JS. Indicative findings of pancreatic cancer in prediagnostic CT. Eur Radiol. 2009;19(10):2448-55.

15. Prokop M, Galanski M. Spiral and multislice computed tomography of the body: Thieme; 2003.

16. Karasawa E, Goldberg HI, Moss AA, Federle MP, London SS. CT pancreatogram in carcinoma of the pancreas and chronic pancreatitis. Radiology. 1983;148(2):489-93.

17. Gangi S, Fletcher JG, Nathan MA, et al.Time interval between abnormalities seen on CT and the clinical diagnosis of pancreatic cancer: retrospective review of CT scans obtained before diagnosis. AJR Am J Roentgenol. 2004;182(4):897-903.

18. Li H, Zeng MS, Zhou KR, Jin DY, Lou WH. Pancreatic adenocarcinoma: the different CT criteria for peripancreatic major arterial and venous invasion. J Comput Assist Tomogr. 2005;29(2):170-5.

19. Wolske KM, Ponnatapura J, Kolokythas O, Burke LMB, Tappouni R, Lalwani N. Chronic Pancreatitis or Pancreatic Tumor? A Problem-solving Approach. Radiographics. 2019;39(7):1965-82.

20. Marchegiani G, Andrianello S, Morbin G, et al. Importance of main pancreatic duct dilatation in IPMN undergoing surveillance. Br J Surg. 2018;105(13):1825-34.

21. Freeny PC, Traverso LW, Ryan JA. Diagnosis and staging of pancreatic adenocarcinoma with dynamic computed tomography. Am J Surg. 1993;165(5):600-6.

22. Shin E, Canto M. The clinical assessment of pancreatic cancer. Diseases of the Pancreas: Springer; 2008. p. 527-40.

23. McNulty NJ, Francis IR, Platt JF, Cohan RH, Korobkin M, Gebremariam A. Multi--detector row helical CT of the pancreas: effect of contrastenhanced multiphasic imaging on enhancement of the pancreas, peripancreatic vasculature, and pancreatic adenocarcinoma. Radiology. 2001;220(1):97-102.

24. Paspulati RM. Multidetector CT of the pancreas. Radiol Clin North Am. 2005;43(6):999-viii.

25. Grieser C, Steffen IG, Grajewski L, et al. Preoperative multidetector row computed tomography for evaluation and assessment of resection criteria in patients with pancreatic masses. Acta Radiol. 2010;51(10):106777.

26. Kim SW, Kim SH, Lee DH, et al. Isolated Main Pancreatic Duct Dilatation: CT Differentiation Between Benign and Malignant Causes. AJR Am J Roentgenol. 2017;209(5):1046-55. 